\title{
Mechanisms for the protection of trademarks not registered in the legal system
}

\author{
Dana Albany Puche Oliveros ${ }^{\# 1}$, Raul J. Martelo ${ }^{* 2}$, Erika Vanessa Herrera Castro ${ }^{\$ 3}$

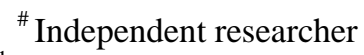 \\ 1anapuchw@hotmail.com \\ * Faculty of Engineering, INGESINFO research group, University of Cartagena, Colombia. \\ ${ }^{2}$ rmartelog1@unicartagena.edu.co \\ \$ndependent researcher. \\ ${ }^{3}$ ErikaVanessaHerrera@hotmail.com
}

\begin{abstract}
The objective of this research was to analyze the protection mechanisms for trademarks not registered in the Venezuelan legal system, for which it was necessary to indicate the legal context of the unregistered trademarks, examine the legal situation and explain the procedure for the registration of trademarks in the legal system. The study was typified as a documentary, with a bibliographic design. The results show among other aspects, that in the Venezuelan legal system marks from a conceptual point of view are well addressed, covering a series of requirements that are considered indispensable to enforce the application for registration. It is concluded that there are different mechanisms that come to assert the rights of who was the intellectual creator of the brand. It also concludes the existence of standards that do not address procedures as such or a law that indicates them, for which an exhaustive analysis must be done in a way that facilitates the interposition of each of these mechanisms.
\end{abstract}

Keyword - Registration, Legislation, Intellectual Property, Industrial Property, Legal Order

\section{INTRODUCTION}

A trademark is a distinctive sign, name, symbol or word that identifies certain goods or services such as those produced or provided by a person or company [1]. Also, each brand name is a brand: a registered trademark if it is used for products, a service mark if it is used for services or a commercial name if it is used as the name of a company; these words, however, are often grouped by convenience under the term 'registered trademark'. From the moment a company chooses a name for itself or its products and services, it must begin to navigate a series of brand problems to protect and manage its brand [2]. In this sense, by being the first to use the trademark in the trade or the first to register it in an official agency, the rights are acquired as owner of the trademark [3]. However, it is important to point out that the simple use of a brand does not grant whoever generates benefits with it, the rights over it.

Because all brand names are trademarks, the management of trademarks inevitably involves issues of trademark law [2]. Therefore, the protection of trademarks that have not been subject to registration constitutes an issue associated with the adopted system, to determine the birth of the exclusive right over a symbol. In countries such as China, only the registered trademark can obtain the rights of the Trademark Law, for which the protection of unregistered trademarks is weak [4]. In this sense, it is appropriate to discern and know what acts or situations could be considered relevant when acting before a competent body; situations such as use, time or finally establish the registration of it as the only resource.

The literature evidences studies on the subject, as it is the case of [5], who in its study explains the consequences of a deficient legal writing, in the process that the action of nullity entails and type of action that corresponds in the judicial demand for the recognition of a better right. Likewise, the article presented by [6], determines the importance that requires a brand to be differentiated from others and that the request for registration be provided in a timely manner.

Now, the mechanism of protection par excellence of the marks is its registration through the procedures previously established by law and the different Institutions that regulate the matter, as it is in Venezuela, the Autonomous Service of Intellectual Property (SAPI), which is in charge of exercising the competence that over intellectual property corresponds to the Venezuelan State. However, it is common to see the lack of registration of some brands in the market, which makes them susceptible to being plagiarized or usurped. Likewise, it is common to see traders or entrepreneurs little interested or misinformed about the system of registration and protection of trademarks, so through this research work, it is sought to determine what is the means of protection offered by the law to these traders and your brands. Therefore, the objective was to analyze the protection mechanisms for brands not registered in the Venezuelan legal system, to provide guidance to the interested parties and to ensure that they are prepared. 


\section{Methodology}

The present investigation was of an applied type, because immediate and concrete solutions are pursued [7]. This type of research is based on the results of basic research, which in turn is subject to a social need to be resolved. Likewise, due to the level of knowledge to be achieved, it is an Exploratory and Descriptive type of research; in the first case because it is an issue that has rarely been explored and on which it is difficult to formulate a precise hypothesis [8]. In the second case because it seeks to specify properties, characteristics and important features of any phenomenon that is analyzed [9]. In this type of research, we seek to know widely the facts that support the study. On the other hand, according to the sources that originate the information or where the data are collected, it was a documentary research, which has the purpose of broadening and deepening the knowledge of its nature, with support, mainly, in previous works, information and data disclosed by printed, audio-visual or electronic media.

\section{A. Research instruments}

The technique used in this investigation was the Documentary Review, which is a technique in which recourse is made to written information, either by taking data that may have been the product of measurements made by others or as a text that in itself constitutes the study events [10]. Bibliographic material of different authors was used, counting on the contribution provided through electronic means of documents related to the subject matter of study, with which the bases that substantiated the level of knowledge reached were obtained.

\section{B. Data analysis}

The Documentary Analysis was used, it constitutes a scientific auxiliary technique of the investigation, of singular importance, because it allows, through an objective intellectual operation, the identification, the objective and systematic description of the elements of the content, meaning and form of the document, and its comparison with other instruments of similar meaning and value [11]. On the other hand, in search of the optimizing of results, Legal Hermeneutics was used, which is defined as the art, science of interpreting legal texts [12]. In the same way, Analogy was used as an available resource to also facilitate the obtaining of results; [13] defines it as "Similarity between different things or ideas, whose application is admitted by Law to regulate, through a case provided for in the Law, another that, being similar, has been omitted to be considered in that".

\section{RESULTS}

Below are the results of the research, obtained through direct documentary observation, based on information collected through bibliographic, doctrinal, scientific journals, research works with a suitable approach to the type of research, refereed articles. Subsequently, the legal sources related to the topic were interpreted and found to be of interest and contribution to the proposed problem, obtaining in this way the results to achieve the research objective, which was oriented to analyze the mechanisms of protection to the trademarks not registered in the Venezuelan legal system. In the first instance, it was necessary to indicate the current Venezuelan legal context of the unregistered trademarks, then, the current legal situation that occurs in Venezuela regarding the protection of trademarks was examined. Finally, the procedure for registering trademarks in the Venezuelan legal system was explained.

In indicating the current Venezuelan legal context, it was noted that at the international level, the World Intellectual Property Organization (WIPO) defines trademarks as follows: "A sign that allows you to differentiate the products or services of one company from those of another. The marks are protected Intellectual Property rights". The above definition can be considered highly applicable, since it encompasses multiple factors, however, limits its scope to companies. On the other hand, the point where it states that "trademarks are protected Intellectual Property rights", differs in part because it suggests that at the time a trademark is created, it is already subject to protection, however, in Venezuela almost all the procedures or rights granted to a person are regulated, either through legislation or other mechanisms such as: manuals, internal policies or regulations and refer to both public and private institutions.

What is sought by means of any possibility of regulation, is that it does not go against the precepts established in the national constitution, being the fundamental norm of a State. Thus, in the case of trademarks, the corresponding registration is necessary to enforce any legal advantage granted by the verification of said procedure. On the other hand, also with an international approach, the North American Free Trade Agreement (NAFTA) in chapter XVIII, part six, article 1708 defines the brand as: "Any combination of signs, which allows to distinguish the goods or services of one person from those of another, including the names of persons, designs, letters, numbers, colors, figurative elements or the shape of the goods or their packaging". Unlike WIPO, NAFTA encompasses brands within a more individual context at a person-to-person level, in order to distinguish their product from that of another, because the distinctive factor is important to the time to establish a brand. 
On the other hand, [14] defines brands as: "A word, name or distinctive symbol, or a device used by a business to distinguish these goods or services from its competitors." Similarly, in [4] they state that: "A brand is a name and / or signal whose purpose is to identify the product of a seller or group of sellers, to differentiate it from rival products". The definitions of the previous authors agree with the general meaning that you want to give the brand. Now, being the national perspective the most relevant to take into account, the Industrial Property Law of the Congress of the Republic of Venezuela [15], in its article 27 does not make exclusive mention of the term trademarks, but nevertheless requires trademarks commercial, such as: Those that include "any sign, figure, drawing, word or combination of words, legend and any other sign that is new, used by a natural or legal person to distinguish the articles it produces, those with which it trades or its own company".

In this sense, the definition of Venezuelan legislation is supported, since it encompasses legal and private persons, both of which may require the registration of a trademark, and also covers a series of prerogatives in order to express the meaning and scope of the same. Using trademarks that have not been subject to registration can generate problems of various kinds, because when proceeding to go before the courts to formalize the application for registration, in most cases it is done in order to achieve a commercial interest, so by not registering implies a high risk in terms of investments that were made, either in advertising or marketing. Now, being the lucrative interest one of the main factors when registering a trademark, this procedure is sometimes omitted, leaving it free for any third party to request it from the Autonomous Intellectual Property Service, omitting its importance for a variety of factors.

The Autonomous Intellectual Property Service (SAPI), as an agency attached to the Ministry of Popular Power for Trade, exercises jurisdiction over the intellectual property that corresponds to the Venezuelan State in matters of Copyright, Trademarks and Patents. It also makes a definition of brands as all figures, signs, combinations of words that have novelty, that is, that is not the product of the copy of another with almost similar characteristics, and can be distinguished from the variety of existing brands in the national territory; it can also be used with both natural and legal persons. It also details a social purpose of: "facilitating people access to the goods and services of their preference, we must avoid any practice that causes confusion."

After studying the current Venezuelan legal context of the unregistered trademarks, we proceed to examine the legal situation that occurs in Venezuela regarding the protection of trademarks. It is appropriate to mention that the Venezuelan legal system is broad because it regulates a variety of matters of social, cultural and economic relevance, among others, allowing regulating the coexistence among citizens. In the case of intellectual property, its regulation is limited because it has not been renewed internally, being the Industrial Property Law, a law of the year 1956, for which it is not adapted to the current reality, In addition, it has not been subject to modifications, which makes it underestimate the scope that it has in terms of the advances that have arisen with respect to the subject in question, and in this way be oriented more in the limits that this has as a result of its ancient legal approach.

When examining the current legal situation, it is important to study the treaties signed and ratified by Venezuela in the field of industrial property, in this sense, the Constitution of the Republic of Venezuela in Article 153 points out in international relations the following: "The Republic will promote and favor Latin American and Caribbean integration, in order to move towards the creation of a community of nations, defending the economic, social, cultural, political and environmental interests of the region". Therefore, despite having such outdated legislation, when the Venezuelan state becomes part of the Andean Community of Nations, it finds a way to regulate the matter more broadly. Likewise, decision 486 is issued, which at the time is mandatory, as in the aforementioned article, international treaties and agreements are given the force of law. The decision contemplates the partial subsistence of the national law in the cases in which it refers to the Internal Law, grants the National Treatment and the Treatment of the Most Favored Nation.

Likewise, Article 153 of the Constitution says that: "The Republic may sign international treaties that combine and coordinate efforts to promote the common development of nations, and that guarantee the wellbeing of peoples and the collective security of its inhabitants." In this way, a way to promote intellectual development is sought seeking support in regulations of international application, in order to ensure the greatest possible protection of the rights of citizens, continues the same article: "For these purposes, the Republic may attribute to supranational organizations, through treaties, the exercise of the necessary powers to carry out these integration processes." With which a certain part of the responsibility is delegated, seeking the optimization of the processes through international organizations.

The article states that in the first place, relations with Latin America will be privileged, within the policies of integration and union with Latin America and the Caribbean, so that it is expected to be a common policy of the Latin American countries. Likewise, all integration agreements, such as the rules adopted within the same framework, will be considered an integral part of the current legal system, as well as direct and preferential application to domestic legislation. Now, Article 98 of the Constitution of the Bolivarian Republic of Venezuela [16], recognizes all creation of the human intellect that has been materialized, promoting the disclosure of information, but in a way, omitting the relevance of the corresponding record when He says: "Cultural creation 
is free. This freedom includes the right to investment, production and dissemination of the creative, scientific, technological and humanistic work, including the legal protection of the author's or author's rights over their works".

In a certain way, the legislator, by including the legal protection that the authors enjoy over their works, does not specify that it be obtained with the respective registration procedure before the offices of the Autonomous Intellectual Property Service, thus being the one in charge of granting legal security through the recognition before third parties of owning the ownership of a brand and the right to use it as it deems convenient, thus avoiding any risk in realized investments. Subsequently, the Venezuelan state in its sovereign power to denounce any treaty that has subscribed, formalizes a complaint addressed to the Cartagena Agreement before the General Secretariat of the Andean Community, which generated a series of discussions, together with the disengagement of the Andean decisions and more specifically of the decision 486 because, ceased from the moment of being interposed, all the rights and obligations derived from Venezuela as a member.

Consequently, Venezuela through all the inconveniences at international level that apply in the matter of intellectual property, has not allowed that it is in the legal vanguard in this point, being as it indicates [17], that is regulated by an anachronistic normative body, that is to say, it is something own of the past, but that happens at present, noticing itself reduced the temporal scope of protection of the patents of invention, thus prohibiting this process for: beverages, food products, preparations, reactions and chemical combinations. The Paris Convention for the Protection of Industrial Property [18], and the Agreement on Aspects of Intellectual Property Rights Related to Trade (of the WTO), are another of the unfulfilled tasks of the Venezuelan State, in terms of the adaptation of the internal regulations to the standards established in its regulations, being reflected in the legislation of the Andean Community, of which it no longer forms a part, having in Decision 486, the possibility of having a series of modern legal institutions that was foreseen in the treaties and that at the time of disengagement, caused a legal backlash in the field of industrial property.

[17] also raises, within its scientific documents, the supervening unconstitutionality of the Industrial Property Law [18], based on the breach of treaties that it has ratified of adapting domestic legislation to the provisions of the treaties, being a law enacted during the validity of the Constitution of the Bolivarian Republic of Venezuela of 1953. It agrees with the author, because the creations of the human intellect surpass more and more what has been expressed as normative to apply for its regulation and its scope is not enough. This is how the protection of trademarks presents important legal gaps. In this sense, the Registry of Industrial Property faces a delay in terms of resolving problems that are within its competence, among which stands out the opposition filed against trademark applications, because in some cases, are left unresolved, a large number of oppositions, which poses a number of disadvantages for this administrative body and for individuals.

On the other hand, the procedure for registering trademarks in the Venezuelan legal system, the Dictionary of the Royal Spanish Academy defines the Registry of industrial property as that "which serves to register patents of invention or introduction, trademarks, trade names and industrial rewards, and to obtain the legal protection of the rights concerning all this". From the above, the importance of the registry is highlighted when it mentions that it allows obtaining the legal protection that concerns its entire structure, that is to say, when creating a brand and making use of it, omitting all the legal procedures that would make it possible to enforce the rights of the creator before anyone who wants to use it. In this case, it refers to the protection, referring to the protection or protection of which they are susceptible.

The Industrial Property Law [17], states that any name or distinctive sign in which the person may have an interest may be registered, even though it is not of a commercial nature, that is, that it is intended for legal protection, despite have a different interest to the lucrative, which is what is sought largely in this type of situations and thus avoid inconvenience. This procedure is done by way of exception the procedure for the registration of trademarks; it is indicated in the Industrial Property Law [18], as well as in the website of the Autonomous Service of Intellectual Property hereinafter identified by its acronym SAPI. Article 37 of the Law establishes that "Everything related to industrial property will be in charge of an office that will be called the Industrial Property Registry", which will be responsible for all the pertinent processing.

However, the situation that arises is that many times the administrative delay in terms of trademarks and patents, is widespread, which would be contrary to the right of petition and timely and adequate response of administrative procedures. The public bodies are not in the capacity to respond to the high demand and at the time of making the request, the interested party must comply with the requirements that make use of their application for registration. Likewise, the figure of the registrar is important because all the documents that it verifies; they deserve public faith. 
Later, the respective search of antecedents is made, in this respect, the article of the Industrial Property Law [18], says: "Every individual has the right to improve the invention of another, but cannot use that invention without the consent of the inventor. Neither the inventor can use the improvement or improvements made without the consent of the author of the improvement ". This procedure can often be cumbersome for the interested party, however, due to the above; the search is carried out, in order to rule out the existence of a maca with the same characteristic. Regarding article 74 of the aforementioned Law, which explains: "For the purposes of priority in the registry, the Industrial Property Registrar shall stamp at the bottom of each application for registration, a note stating the date and time of filing; and will give the interested party, signed signature of the presentation with the annotations expressed. "

It is important to comply with each one of the guidelines expressed in the Law, because it would allow a control of the activities carried out in the search of the objectives, both for the official and for the person interested in registering. After verifying the procedures, it is observed that if one of the necessary formal requirements is not met, article 75 says: "If the applicant does not comply with the requirements established in Article 71 of this Act, the Registrar will return the interested party's application, stating the reasons for the refund." It is important to present the reasons why the application for registration is justified, which would allow the interested party to correct his error and comply with the established guidelines to effectively complete the required and obtain the registration title.

Likewise, the same article says that: "The return of the application in accordance with this article, does not extinguish the priority of the presentation if within thirty days, counted from the date of the return, the application with the corrections is reproduced of the case", Thus, the Registrar is entitled to extend this term for up to three months, upon request of the interested party and provided the nature of the matter so requires. Article 77 of the aforementioned Law states that at the time of the publication of the Industrial Property Bulletin, any person who wants to oppose the request and object to the granting of the trademark, may do so within 30 days of its publication.

These are mechanisms with which the legislation seeks in some way to sustain inconveniences that may arise, however, is not very specific in this regard, because it should be an extensive and detailed reading to discern those mechanisms applicable. The procedure for the registration of trademarks can be extensive and tedious in many ways, but what makes it very difficult to carry out in some sectors is its location, since for its formalization it is necessary to go to the offices that are located in the city of Caracas. In the case of any opposition made by a third party, the Autonomous Intellectual Property Service must inform to the notifier also through the Bulletin, so that within the time frame applicable to it, it may assert the arguments on which it bases its opposition and submit the tests if you consider it relevant.

In this way the Law tries not to harm anyone who is interested in the process, but it could be considered that sometimes it is cumbersome, because the existence of this Bulletin is largely unknown, because oppositions are presented after the entire process has been completed and formalized, which is uncomfortable for the registrant, but in a way it is a way to enforce the rights of the third party who did not register the mark in a timely manner. If this is the case, the Law provides a deadline to answer the opposition, which is appropriate, and if it is not, it will be considered that the request has been abandoned. In the opposition, the Registrar must analyze and decide whether the registration of the trademark is appropriate or not; if the opposition is deemed appropriate, the trademark will be denied. If, on the contrary, the opposition does not proceed, the registration of the trademark will follow the procedure of law. The foregoing is executed to avoid any legal inconvenience in the future, for which, the legislator tries to ensure the protection of the rights of both parties.

On the other hand, it happens many times in any type of process, that there has been no opposition to the registration of the trademark or has been declared without place. In this case, the Intellectual Property Registrar will proceed to perform the background or registration examination. If this is approved, it will grant the registration of the trademark and it will be published in the Bulletin as granted, as indicated in article 81 of the Industrial Property Law [18]. Similarly, article 83 explains that during the 30 business days following its publication in the Bulletin as a granted trademark, registration fees must be paid in order for the Autonomous Industrial Property Service to precede issuing the respective certificate.

In case the trademark is denied, as it is in any of the cases contemplated in articles 33, 34 and 35 of the Law, the corresponding administrative resources may be exercised in accordance with the provisions of articles 94 and 95 of the Law Organic Administrative Procedure (LOPA). According to the provisions of Article 84 of the Industrial Property Law [18], the nullity of the registration of a trademark that has been granted to the detriment of the right of a third party, may be requested before the competent courts, if the interested party does not he had made the opposition to the contraction of article 77 of the same Law. This action can only be attempted within two years, counted from the date of the certificate. 
Finally, when analyzing the protection mechanisms for trademarks not registered in the Venezuelan legal system, it can be said that there are multiple mechanisms in the Law, which, although not expressed in that way, are those that would allow asserting the claim of the creator of a brand that did not make the timely registration. At the national or regional level, a trademark can be protected by registering it, that is, submitting an application for registration at the national or regional trademark office and paying the corresponding fees. At the international level, there are two options: submit a trademark application in the trademark office of each of the countries in which you want to obtain protection, or use the Madrid system as a centralized solution for trademark registration and management throughout the world. Simply submit a single application, in one language, and pay an exclusive fee to protect your brand in the territory of up to 97 members, whose management of brands will be carried out through a centralized system, according to information extracted from the World Intellectual Property Organization.

The mechanisms that help to guarantee the protection in the case of unregistered trademarks are little known, due to the ignorance of the Law, or by other factors that affect an erroneous interpretation of it. The case in question is presented when the intellectual creator has materialized the result of his intellect, that is, the brand gives its origin, but the registration procedure is omitted when not addressing the competent bodies to formalize the registration, which allows the plagiarism of it. In the first place, the Opposition for Better Law is proposed within the trademark context, the teacher [19] defines the best law as "any advantage that one party holds and presents in relation to another". Being a definition that covers a large number of situations, its study applicable to the situation, is relevant because it is a tool or mechanism that can be used to assert the claim of opposition of a brand to have a better right to a third, however, it is not used solely in the trademark sense, as it is adaptable to multiple legal situations because it does not limit the meaning to which its application is intended.

In this regard, [19] affirms that the brand may or may not register with a commercial interest, however, when performing all the registration procedures, what is sought is to be able to make use of it and in most cases it is a trade purposes. Now, Venezuelan law, states in Article 77 of the Industrial Property Law [18], that: "For thirty business days counted from the date of publication in the Industrial Property Bulletin, any person may object to the request and oppose the granting of the trademark...". This is where you can assert the rights as the intellectual creator or owner of the brand, to present any legal advantage in relation to another person, making use of the power to address any body and make your request sued. It is important to recognize the procedure, because one of the disadvantages to take into account, refers to the brands that have not been registered, can be requested by any interested party who goes to the corresponding Registration Office to formalize their application. That is, anyone who obtains the trademark registration can contact any third party to request that they stop making use of it or demand economic benefit so that they can continue to use it.

It must be clarified that the application for trademark registration is a petition, the action being by right a better action. To formalize the opposition must make a petition that must be filed with the Registrar of Industrial Property later, claiming the opponent who has a better right to obtain registration of the mark requested a third party, either in relation to a certain brand, a commercial name or a commercial slogan. The Industrial Property Law [18] does not establish any special requirement that the document must contain, since at the time of writing it should assume the characteristics of a petition, following the provisions of the Code of Civil Procedure, regarding drafting, that is, to what is prescribed in article 340. Any person cannot present or interpose the opposition, this motivated to have to have a real interest in the process and argue about what is based on your request for the opposition, that is, as noted [20]: "should be assumed holder of subjective rights, prevailing over those of the applicant", also states that it must have a current legal interest being the failure of one of the conditions of the action.

Another of the solutions proposed by the legislation is the nullity action, but in the first place the concept of action will be studied only, being understood as that initiative to address before the corresponding jurisdictional bodies to claim before a court, with which, any skilled person and with legal interest, can appeal before the competent organisms, also, as for the nullity action, authors as [21] present a definition that adapts to the Venezuelan context, conceptualizing it as: "The legal means by which it is demanded that an obligation be canceled that does not have all the conditions required for its validity", that is, to consider using this mechanism, a series of requirements must be met. On the other hand, it is indicated in the Industrial Property Law [18] in its article 84 the annulment action for the better right, as follows: The nullity of the registration of the trademark that has been granted to the detriment of the right of a third party may be requested before the competent courts, if the interested party has not made the opposition to which article 77 of this Law is contracted.

This action can only be attempted within two years, counted from the date of the certificate. From what can be extracted from the concept extracted from the legislation, is that to be able to use this medium, in the first place there had to be no opposition, likewise, a lapse is established in which this action can be attempted, specifically within two years from the date of the certificate. What is discussed in the nullity action for a better right is no more than the ownership of the registration of a trademark, slogan or trade name. [5] states in its arbitrated article, that the nullity of a trademark registration because of the better right of a third party, do not 
seem to be an absolute nullity since there is no express violation of the law or public order. In addition, it would be imprescriptible. In reality, the nullity action for a better right does not go beyond being litigation between merchants for the ownership of a trademark, a denomination or a commercial slogan.

At an international level [22], transcribes article 50.1 of the Spanish Trademark Law, which states as follows: "The declaration of nullity implies that the registration of the trademark was never valid, considering that the registration or the application that originated it did not have the effects provided for in title IV, first chapter, of this Law, to the extent in which the nullity has been declared". From the above, it is understood that both the application and the registration were never valid if their nullity was requested, an extremist point of view than that of another part of the doctrine, and an absolute nullity could be elucidated, but as it was studied in other points, what is intended to determine is not the scope of the action but who owns the registration, but also serves as a reference to the object of study providing an international approach to the Spanish legislation.

Similarly, precautionary measures are another protection mechanism for trademarks that have not been subject to registration in the situation, thus, [23] does not refer to precautionary measures as such, but identifies them as a precautionary measure and explains them saying: "It is the provisional anticipation of certain effects of the final providence, aimed at preventing the damage that could result from the delay of the same." Precautionary measures may be requested for the improper use of a trademark by a third party, and certain conditions must be met for its application, whether the trademark is registered; in the commercial or industrial end that this one must possess with the pertinent exceptions to the case; the absence of tolerance or consent on the part of the registrant so that his trademark is used by a third party and finally it is necessary that the principle of offense exists, that is, that the behavior of the offender generates a risk of confusion in the market.

On the other hand, [24] states that: "precautionary is called the process when, instead of being autonomous, it serves to guarantee (it constitutes a precaution for the successful completion of another definitive process)". In this regard, the Spanish Civil Procedure Law [25], in its article 721.1 part in fine, establishes: "The precautionary measures are those measures necessary to ensure the effectiveness of the judicial protection that could be granted in the ruling that is dictated." It can be summarized after studying different meanings, what is sought with the execution of precautionary measures is to guarantee the end of the process and has as complementary purposes, that the infringing brand is not still used during the main trial and, as a consequence, that protect the consumer and commercial traffic; the second purpose is to ensure that the execution of what is decided in the ruling does not become illusory when the plaintiff wants the sentence to be executed.

\section{CONCLUSION}

The above results allow us to conclude that the brands from a conceptual point of view are well addressed, covering a series of requirements that are considered indispensable to enforce the application for registration. Similarly, in Venezuela, brands have legislation that regulates them, with the Industrial Property Law is their main source of study, despite not being in some aspects adapted to the present with a validity dating back to 1956; however, it also applies in the matter. On the other hand, regarding the current legal situation of the protection of trademarks that is presented in Venezuela, it is concluded that the legal system recognizes and accepts intellectual property at a constitutional level, proposing the different mechanisms through which it can be protected.

With this recognition, it is evident the essentiality and the importance that in this country have the means of protection offered by our legislation to the different works of the mill, among these brands, such as symbols or names designed to distinguish a product from its competence. However, it is common to observe that these brands, despite being exploited in the market, are not protected by their owners through their registration, and that is why the Industrial Property Law establishes certain protective mechanisms for these unregistered trademarks. However, this regulatory body is not clear about this, since although it recognizes a certain extent the need to protect these unregistered trademarks, it is also not specific when determining a procedure for the protection of these trademarks, which is then translated in disinformation for consumers.

Regarding the procedure for registering trademarks in the Venezuelan legal system, it is concluded that the Industrial Property Law outlines the procedure to be followed for the registration of a trademark in Venezuelan legislation, which can be seen on the website of the Autonomous Intellectual Property Service (SAPI), it contains a series of procedures to be followed by the intellectual creator of the brand.

Finally, it is concluded that the Venezuelan legal system identifies different mechanisms that come to assert the rights of the intellectual creator of the brand, and the Law of Industrial Property points out the different mechanisms that can be used, the opposition being by better right, the nullity action for better right and the precautionary measures the main ones to take into account. It also concludes the existence of standards that does not address procedures as such or a law that indicates them, inasmuch as an exhaustive analysis must be done in a way that facilitates the interposition of each of these mechanisms. 


\section{REFERENCES}

[1] D. Vohora and G. Singh, (Eds.) Pharmaceutical Medicine and Translational Clinical Research, Chapter 17 - Trademark. Academic Press, 2018.

[2] T.A. Lemper, "Five trademark law strategies for managing brands,” Business Horizons, vol. 55, no. 2, pp. 113-117, 2012.

[3] Y. Mealem, Y. Yacobi Y. and G. Yaniv, "Trademark infringement and optimal monitoring policy,” Journal of Economics and Business, vol. 62, no. 2, pp. 116-128, 2010.

[4] W. Stanton, M. Etzel and B. Walker, Fundamentos de Marketing, 11th edition. México: Editorial McGraw-Hill, 2000.

[5] J.M. Carrascosa, “La Acción de Nulidad por Mejor Derecho en el Sistema Marcario Venezolano,” Propiedad Intelectual, vol. XII, no. 16, pp. 87-111, 2013.

[6] G.T. López, “La Distintividad como Requisito Fundamental para el Registro de una Marca,” Propiedad Intelectual, vol. XI, no. 15, pp. 137-153, 2012.

[7] S.C. Vélez, Apuntes de metodología de la investigación, un resumen de las principales ideas para el desarrollo de proyectos de investigación. Medellín, Colombia: Universidad Escuela de Administración, Finanzas e Instituto Tecnológico, 2001.

[8] F.G. Arias, El Proyecto de Investigación. Introducción a la metodología científica, 5th. Edition. Fidias G. Arias Odón, 2012.

[9] R. Hernández, C. Fernández and P. Baptista, Fundamentos de metodología de la investigación. New Jersey, USA: Mc Graw-Hill, Hoboken, 2010.

[10] J. Hurtado de Barrera, Metodología de la Investigación Holística. Servicios y Proyecciones para América Latina (SYPAL). Caracas Venezuela, 2012.

[11] J.W.B. Chacón, J.C.B. Herrera and M.R. Villabona, "Revisión y análisis documental para estado del arte: una propuesta metodológica desde el contexto de la sistematización de experiencias educativas,” Investigación Bibliotecológica: archivonomía, bibliotecología e información, vol. 27, no. 61, pp. 83-105, 2013.

[12] G. Cabanellas de las Cuevas and E.C. Hoague, Diccionario jurídico, Law dictionary: english-spanish, español-inglés/Law dictionary. Heliasta Editorial, 2001.

[13] L. Cabanellas, Diccionario Enciclopédico de Derecho Usual. Heliasta Editorial, 1979.

[14] E.L. Richards, Law for Global Business, p. 334. USA: Richard D. Irwin, Inc., 1994.

[15] Congreso de la República de Venezuela (1956), Ley de Propiedad Industrial. Caracas, Venezuela: Gaceta Oficial No. 25.227, 1956.

[16] Constitución de la República Bolivariana de Venezuela (1999). Caracas, Venezuela: Gaceta Oficial No. 36.860, 1999.

[17] L.G. Arévalo, "El Principio de Legalidad, la Constitución y la Situación de la Propiedad Industrial en Venezuela,” Propiedad Industrial, vol. XI, no. 15, pp. 227-244, Mérida, Venezuela: Universidad de los Andes, 2012.

[18] Paris Convention for the Protection of Industrial Property of March 20, 1883, revised in Brussels on December 14, 1900, in Washington on June 2, 1911, in The Hague on November 6, 1925, in London on 2 June 1934, in Lisbon on October 31, 1958, in Stockholm on July 14, 1967 and amended on September 28, 1979.

[19] V. Bentata, Los temas críticos en propiedad industrial. Mérida, Venezuela, 2002.

[20] J.M Carrascosa, "La Oposición por Mejor Derecho en el Sistema Marcario Venezolano," Propiedad Intelectual, vol. XI, no. 15, pp. 90110, 2012.

[21] L. Sanojo, Instituciones de derecho civil venezolano, Tomo III, p.173. Madrid, España: Alonso Editions, 1953.

[22] N.C. Fernández, Tratado sobre derecho de marcas, p. 521. Madrid: Marcial Pons Ediciones Jurídicas y Sociales S.A., 2001.

[23] P. Calamandrei, Providencias cautelares, p.45. 1984.

[24] F. Carnelitti, Instituciones de Derecho Civil, Tomo I, p. 86. 1973.

[25] Spanish Civil Procedure Law, artículo 721.1 in fine, 2000.

\section{AUTHOR PROFILE}

Dana Albany Puche Oliveros works as independent researcher. Mrs. Puche completed his magister from Rafael Belloso Chacin University (Venezuela). Mrs. Puche completed his undergraduate in Law at the Rafael Belloso Chacin University.

Raúl J. Martelo works as full-time professor at the University of Cartagena (Colombia). Mr. Martelo completed his magister from Industrial University of Santander (Colombia). Mr. Martelo completed his undergraduate in Systems Engineering at the Industrial University of Santander.

Erika Vanessa Herrera Castro Lawyer of the University of Cartagena, specializing in Public Law of the Externado University of Colombia- Bogotá. Master's student in Political Science and Governance at Universidad del Norte Colombia-Barranquilla 